\title{
'n Verfynde siening van die inspirasie en die gesag van die Bybel
}

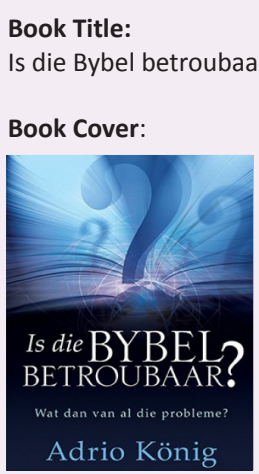

Author:

A. König

ISSN:

978-1-4316-0713-6

Publisher:

Vereeniging: Christelike

Uitgewersmaatskappy, 2013

R179.95*

*Book price at time of review

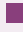

Review Title:

'n Verfynde siening van die inspirasie en die gesag van die Bybel

Reviewer:

Rudy A. Denton ${ }^{1}$

\section{Affiliation:}

${ }^{1}$ Faculty of Theology,

North-West University,

Potchefstroom Campus,

South Africa

Email:

rudydenton@vodamail.co.za

Postal Address:

PO Box 20015, Noordbrug

2522, South Africa

How to cite this book review:

Denton, R.A., 2014, "n

Verfynde siening van die

inspirasie en die gesag van

die Bybel', In die Skriflig

48(1), Art. \#1805, 1 page.

http://dx.doi.org/10.4102/

ids.v48i1.1805

\section{Read online:}

Scan this QR code with your smart phone or mobile device to read online.
Die tema van die publikasie, Is die Bybel betroubaar?, handel oor die kritiese kernvraag sowel as die argumente vir of teen die historiese betroubaarheid van die Bybel. Die outeur, Adrio König slaag inderdaad in die doelstelling van die publikasie, naamlik om 'n verfynde siening van die inspirasie en die gesag van die Bybel daar te stel. Die hart van die publikasie word in ongeveer sewentig stellings en standpunte uiteengesit. Dit impliseer ' $n$ duidelike beskrywing van die boodskap van die Bybel, die gesag en betroubaarheid daarvan, die verbond, Jesus, God, die verhouding Ou Testament - Nuwe Testament, die apokriewe boeke, inspirasie, maniere van Bybellees, Bybelvertalings en vertaalteorieë, die geskiedenis in die Bybel, die geskiedenis van die Bybel, Israel, die heil en heilsweg en die opstanding. Die teologiese hantering van die publikasie oor die historiese betroubaarheid van die Bybel word op 'n verantwoordbare en breedvoerigteologiese wyse hanteer.

Die besondere manier waarop die tema in die publikasie hanteer word, is om deur ' $n$ wyer bespreking met bybelsgefundeerde bewyse alle twyfel aangaande die historiese betroubaarheid van die Bybel af te weer. In elf hoofstukke begrond die outeur sy bybels-teologiese navorsing. Hoofstuk een beskryf die probleem wanneer die Bybel en geloofsake in die gedrang kom. Hoofstuk twee en drie handel oor die sentrum en boodskap van die Bybel en word opgevolg deur die ontstaan en samestelling van die Bybel in hoofstuk vier. Die gesag en betroubaarheid van die Bybel word in hoofstuk vyf bespreek, gevolg deur 'n beskrywing van die hermeneutiese uitlegteorie in hoofstuk ses en die eksegetiese uitlegmetodes in hoofstuk sewe. Hoofstuk agt verwoord verskillende wyses van Bybellees wat op verskille in die Bybel uitloop in hoofstuk nege en probleme en probleemtekste in hoofstuk tien. Hoofstuk elf verwoord 'n persoonlike belydenis aangaande die inspirasie en die gesag van die Bybel.

Die publikasie is ' $n$ handige verduideliking van verskillende benaderings en standpunte omtrent die Bybel. Dit is sodanig geskryf dat teoloë en gelowiges die historiese betroubaarheid, die inspirasie en die gesag van die Bybel kan begryp. Die publikasie is 'n waardevolle wetenskaplike bydrae tot die Teologie en 'n verfynde siening, deur die oë van die outeur, van die inspirasie en die gesag van die Bybel as die betroubare woord van God. Dit wek opgewondenheid om die publikasie deur te werk en die onderwerp, vanuit König se perspektief, beter te verstaan.

Hierdie publikasie kan aanbeveel word vir persone wat in hulle bestudering van die Bybel dieper delf - mense wat die Bybel ontdek as 'n onuitputlike rykdom in verskeidenheid wat veel meer is as ' $n$ blote historiese bron. Hierdie is inderdaad ' $n$ bruikbare boek om die hedendaagse stortvloed van kritiek en probleme vierkantig in die oë te kyk en die Bybel as geloofwaardig te glo. Die skryfstyl is maklik verstaanbaar, maar tog keurig - 'n kritiese antwoord op die twyfel van hiper-kritiese teoloë. Die publikasie getuig van deeglike navorsing en dit kan met vrymoedigheid aanbeveel word. 